\title{
IN THE MUSEUM
}

\section{A J Ryan (University of KwaZulu-Natal, Durban)}

The Museum of Classical Archaeology has recently acquired a number of new Roman artefacts. Of these, the most interesting is a small fragment of a bronze Flavian Roman military diploma (Durban 2007.52), the subject of this contribution. The fragment is from Table I of a diploma and measures $5.39 \mathrm{~cm} \times 2.88 \mathrm{~cm}$, is $1.2 \mathrm{~mm}$ thick with letters averaging $4.5 \mathrm{~mm}$ high. Typically a complete diploma would be around $21 \mathrm{~cm} \times 16 \mathrm{~cm}$. Not only is this diploma a valuable piece of documentary evidence, but it is also the first example of Roman writing in our museum. The acquisition of this new addition to our collection is thanks largely to a generous donation by Ms Joan Law.

Military diplomas, awarded to veterans of the Roman auxilia, are amongst the most useful documentary sources for Roman military and frontier history. The Roman army consisted not only of citizen troops but also of auxiliary units - recruited noncitizens from the provinces. Auxilia would most often be recruited into either infantry units called cohorts, or cavalry units called alae. First used by Caesar during the civil war as mercenaries, gathered from local tribes to supplement his legions, the auxiliaries began to play an increasingly important role in Roman military strategy during the $1^{\text {st }}$ century AD. ${ }^{1}$

By the Flavian period, the auxiliaries were a permanent professional army whose units were commanded by senior equestrian Roman officers. These foreign troops added depth to the Roman war machine as, since they were skilled in the weaponry of their own nations, they broadened the range of strategies at the disposal of the generals. The auxiliary units were generally named after the province from which they were recruited (for example, I Thracum from Thrace) although the tendency was for them to be stationed outside of their home province. After serving for 25 years with the Roman army, auxiliary veterans, and their respective wives ${ }^{2}$ (and until 140 AD their children), were granted Roman citizenship. ${ }^{3}$

Proof of this grant was formalised by two sets of bronze documents. The first, called the constitution, was a single bronze plate that was hung up on the temple of Augustus in Rome. The second set of documents consisted of the diplomas: multiple copies of the relevant portions of the constitution that were given to the individual soldiers who qualified. Roxan has argued that these diplomas were not issued to every soldier, but only those who paid for them. ${ }^{4}$ Her reasoning is that cavalry diplomas are statistically well over-represented.

$1 \quad$ The classic texts on the subject are Cheesman 1914 and Saddington 1982.

2 Strictly speaking the auxiliaries couldn't marry while they were in active service. Furthermore, citizens could not legally marry non-citizens. Therefore, most diplomas made provisions for the veteran to legal marry a non-citizen and have heirs who could inherit. This provision held for only the first marriage. Subsequent marriages to a non-citizen were not legal and thus the children of which could not fully inherit.

$3 \quad$ Mann 1972:236 n.8.

$4 \quad$ Roxan 1986:266, a sentiment echoed by Mann 2002:183. 
Since most auxiliaries settled in the place at which they were stationed, ${ }^{5}$ it is unlikely that such troops would have required diplomas as evidence of citizenship since they would be known from the local garrison. Furthermore, their Roman citizenship would be a social marker, setting them apart from their neighbours and indeed making it unlikely that they would have to prove their citizenship with the document. On the other hand, diplomas were probably necessary for itinerant veterans who might have purchased land elsewhere.
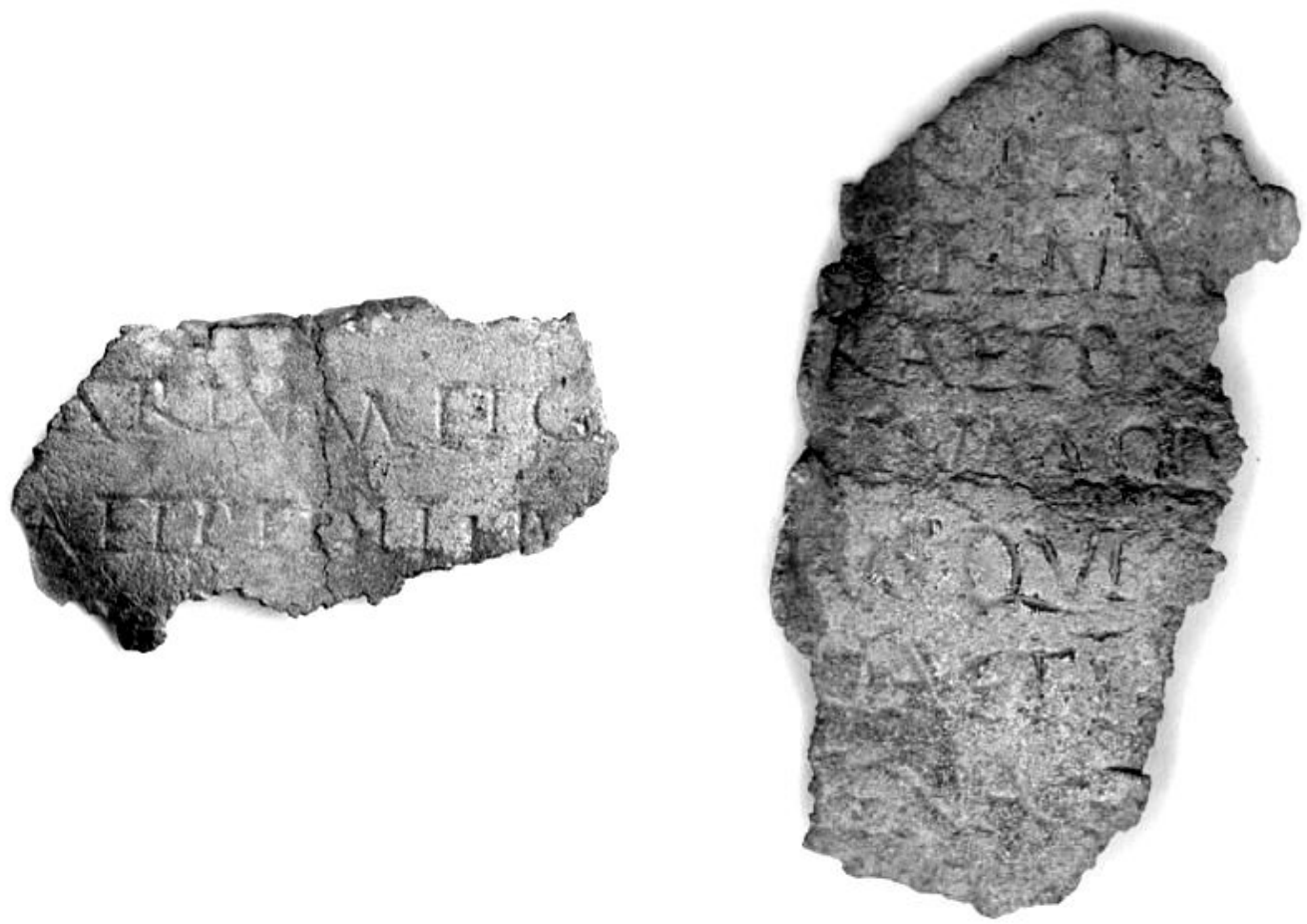

Fig. 1. Durban 2007.52 extrinsecus.

Fig. 2. Durban 2007.52 intus.

Complete diplomas were always constructed according to a set formula. They consisted of two tables. The tables were inscribed on both sides with more or less the same text and were bound together with wire through two holes in the centre and then sealed such that if the outside (extrinsecus) of the diploma were to be defaced or altered in any way, it could always be opened to reveal another copy of the original text on the inside (intus). It is quite common that the outside, which was intended for public display, was rendered with considerably greater care than the outside, which was often rushed.

\footnotetext{
5 A useful practice from the Imperial perspective, since they could always be called upon by their respective legions should the need arise.
} 
The text of the diploma is set according to a standard formulaic pattern. The first part of the text is copied directly from the constitution in Rome and contains:

* the name of the emperor under which the diploma was issued, together with his honours and the number of times he has held these honours,

* the names of all the units into which men granted citizenship that day had been enrolled,

* the province in which these units were stationed and the name of the provincial governor,

* the terms of the citizenship grant

* the date, month and the names of the consuls

From this point, the individual diplomas differ from the constitution. The constitution lists the names of all the soldiers granted citizenship that day, while the diploma indicates the name and details of both its owner and the unit to which he belonged. Finally the diploma also has, usually on table II extrensicus, a list of witnesses to the copying and the sealing of the document.

Because of the formulaic nature of diplomas, it is often possible for them to be interpreted even if only a small portion of the text remains. In the first instance, the manner in which the legal formula is composed is quite regular for any given period and furthermore, the way in which these formulae changed over time has been well documented according to the so-called Alföldy-Mann classification system. ${ }^{6}$ Thus, even if only a handful of letters are preserved, it is possible for the text on a diploma to be reconstructed with a reasonable degree of certainty. Although purchased from a reputable dealership, the Durban piece was supplied with only a vague provenience and date. Furthermore not only is it a small fragment, but the letters, in places, are difficult to discern. To this end, the fragment was scanned and rudimentary image processing carried out to distinguish the lettering from the background. The results are illustrated in figures 3a. and 4a.

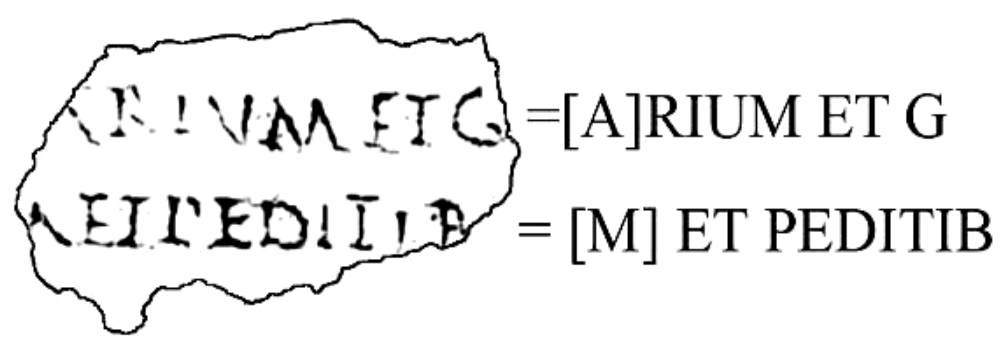

Fig. 3a extrinsecus: processed image and Fig. 3b text.

$6 \quad$ Alföldy 1968 and Mann 1971. 
Next, the lettering was deciphered as illustrated by figure $3 \mathrm{~b}$ and $4 \mathrm{~b}$ (box brackets indicate that a given letter is not completely discernable).

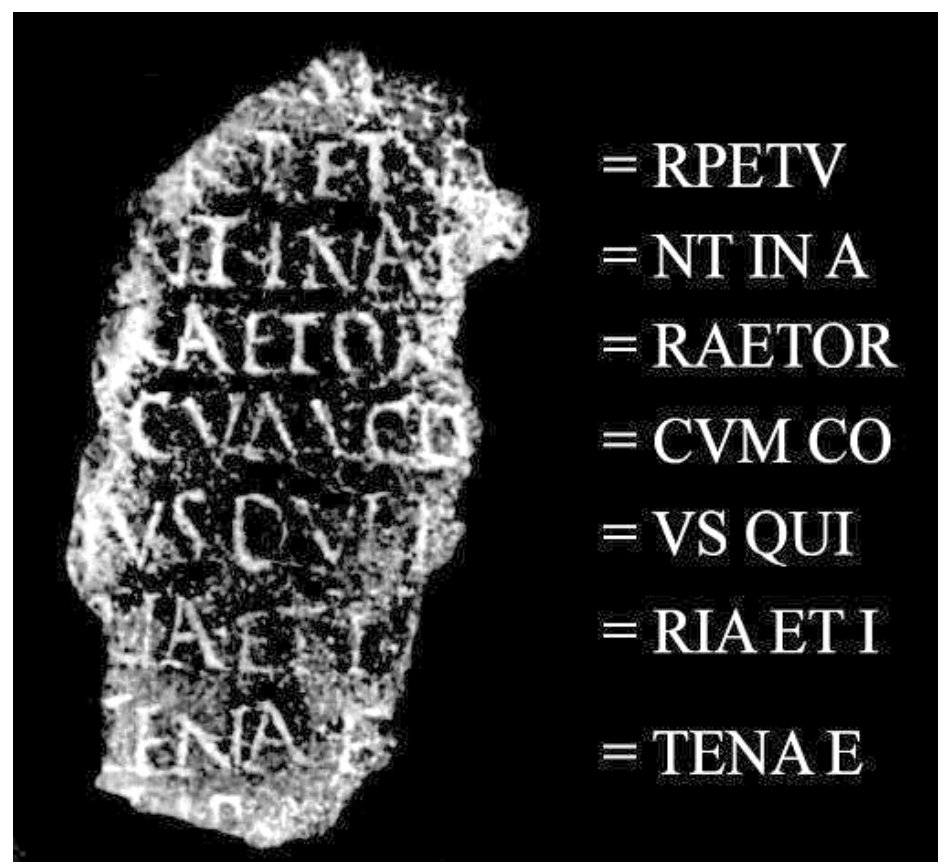

Fig. 4 intus: a) processed image and b) text.

The text, as it turns out, fits almost precisely to another diploma in Sofia that has survived completely intact. ${ }^{7}$ The relevant parts of the Sofia diploma are transcribed below with bold capitals indicating the text that matches that of the Durban fragment.

Imp(erator) Caesar divi Vespasiani f(ilius) Domitianus Augustus Germanicus pontifex maximus tribunic(ia) potestat(e) $X$ imp(erator) $X X I$ co(n)s(ul) $X V$ censor pERPETU $\mathrm{E}$ (ater) p(atriae)

equitibus qui militaNT IN Alis tribus III Thracum Augusta et Flavia pRAETORia singulARIUM ET Gallorum et ThraCUM COnstantiuM ET PEDITIBus et equitiBUS QUI in cohortibus septem I Thracum milliARIA ET I Gaetulorum et I Lucensium et I SebasTENA ET II Thracum civium Romanorum et II Thracum civium Romanorum et II Thracum Syriaca et II Italica civium Romanorum quae sunt in Syria sib A(ulo) Bucio Lappio Maximo qui quina et vicena plurave stipendia meruerunt item dimissis honesta missione emeritis stipendiis

quorum nomina subscripta sunt ipsis liberis posterisque eorum civitatem dedit et conubium cum uxoribus quas tunc habuissent cum est civitas iis data aut si qui caelibes essent cum iis quas postea duxissent dumtaxat singuli singulas

RMD ${ }^{1}$ 4, AE 1962.0319B, Epigraphische Datenbank Heidelberg HD018034. 
a(nte) d(iem) IIII Idus Maias P(ublio) Valerio Marino Cn(aeo) Minicio Faustino co(n)s(ulibus) alae III Thracum Augustae cui pra(e)est M(arcus) Terentius M(arci) f(ilius) Pol(lia) Quirinalis gregali Quelse Dolae f(ilio) Thrac(o) descriptum et recognitum ex tabula aenea quae fixa est Romae in muro post templum divi Aug(usti) ad Minervam

The list of legions from which the diplomates in this diploma are drawn is large and it is likely that many diplomas were issued from this constitution and thus not surprising that duplicates be found. Given the number of points at which the Durban fragment matches the diploma in Sofia, it is probable that they both issued from the same constitution. If this conjecture is correct, then it is possible to establish a date for the Durban diploma by reading the diploma in Sofia. On the latter, Domitian's title indicates he had served 15 consulships and held the title Imperator for the $21^{\text {st }}$ time, indicating 91 AD. Furthermore, the consuls are listed as Minucius Faustinus and Valerius Marinus who were suffect-consuls in May / August $91 \mathrm{AD}^{8}$ and the date, iiii idus maias, is the $12^{\text {th }}$ of May. A secure provenience for the Durban diploma is more difficult to establish. The legions in the Sofia diploma are stationed in Syria but, as I have already stated, many diplomas are found outside of the provinces in which the legions were stationed. The provenience for the Sofia diploma is Bulgaria, but again, this does not mean that the Durban diploma is from the same region. Even if one rejects the attribution of the Durban diploma with the same constitution as that from which the Sofia constitution is copied, the Durban diploma may be dated roughly by the RPETV on the intus which can only be part of the phrase Censor Perpetuus. From 85 AD till his death in 96, the emperor Domitian, who held the senate in very low esteem, assumed permanent control of the office of censor - the traditional role of which was, among other things, to regulate entry to the senate. Thus we can securely date the Durban diploma to between 86 and 96 AD.

\section{BIBLIOGRAPHY}

Alföldy, G 1968. Zur Beurteilung der Militärdiplome der Auxiliarsoldaten. Historia 17: 215-227.

Cheesman, G L 1914. The Auxilia of the Roman imperial army. Oxford: Clarendon. Gallivan, P 1981. The Fasti for A.D. 70-96 CQ ns 31.1: 186-220.

Jones, B W 1973. Some thoughts on Domitian's perpetual censorship. CJ 68.3: 27677.

Mann, J C 1972. The development of auxiliary and fleet diplomas. Ep. St. 9: 233-41.

Mann, J C 2002. The settlement of veterans discharged from auxiliary units stationed in Britain. Britannia 33:183-88.

Roxan, M M 1978. Roman Military Diplomas 1954-1977 BICS Suppl. 2. (RMD ${ }^{1}$ ) London: Institute of Classical Studies.

Roxan, M M 1986. Observations on the reasons for changes in formula in diplomas circa AD 140. In Eck, W \& Wolff, H (eds), Heer und Integrationspolitik: Die

8 According to the Fasti for the Flavian years established Gallivan 1981: 218. 
römische Militärdiplome als historische Quelle, 265-92. Köln: Passauer Historische Forschungen 2.

Saddington, D B 1982. The development of the Roman auxiliary forces from Caesar to Vespasian (49B.C. - A.D. 79). Harare: University of Zimbabwe Press. 